\title{
Penguatan Ekonomi Lokal Pada Pelaku UMKM Berbasis Digital Di Desa Winduaji Kabupaten Brebes
}

\author{
Achmad Zaki Yamani ${ }^{1 *}$, Arif Wirawan Muhammad², Muhammad Nur Faiz ${ }^{3}$ \\ ${ }^{1}$ Program Studi Teknik Industri, Institut Teknologi Telkom Purwokerto, Indonesia \\ ${ }^{2}$ Program Studi Teknik Informatika, Institut Teknologi Telkom Purwokerto, Indonesia \\ ${ }^{3}$ Jurusan Teknik Informatika, Politeknik Negeri Cilacap, Indonesia \\ Email: ${ }^{1}$ zaki@ittelkom-pwt.ac.id, ${ }^{2}$ arifw.muhammad@gmail.com, ${ }^{3}$ faiz@pnc.ac.id
}

\section{INFORMASI ARTIKEL}

\section{Data artikel:}

Naskah masuk, 31 Juli 2019

Direvisi, 27 Agustus 2019

Diterima, 31 Agustus 2019
Kata Kunci:

UMKM

Teknologi

Informasi

\begin{abstract}
ABSTRAK
Abstract- In the industrial era 4.0, technological knowledge, especially information technology is very important. UMKM are micro-enterprises that should have used the information access for the economic welfare of a region, but vice versa. Current problems with UMKM include lack of capital and knowledge of information technology. Winduaji village is one of the villages with UMKM actors with minimal information technology knowledge. The method of implementation is the method of discussion with the format of Training regarding identifying problems to the use of technology media. This training activity was attended by 56 participants consisting of village officials, UMKM actors, and tourism conscious reservoirs. As a result, all participants showed great interest in using social media marketing continuously.
\end{abstract}

\begin{abstract}
Abstrak- Pada era industri 4.0, pengetahuan teknologi, khususnya teknologi informasi sangat penting. UMKM adalah perusahaan mikro yang seharusnya menggunakan akses informasi untuk kesejahteraan ekonomi suatu daerah, tetapi sebaliknya. Masalah saat ini dengan UMKM termasuk kurangnya modal dan pengetahuan tentang teknologi informasi. Desa Winduaji adalah salah satu desa dengan pelaku UMKM dengan pengetahuan teknologi informasi minimal. Metode implementasi adalah metode diskusi dengan format Pelatihan mengenai mengidentifikasi masalah dengan penggunaan media teknologi. Kegiatan pelatihan ini dihadiri oleh 56 peserta yang terdiri dari pejabat desa, pelaku UMKM, dan waduk yang sadar pariwisata. Akibatnya, semua peserta menunjukkan minat besar dalam menggunakan pemasaran media sosial secara terus.
\end{abstract}

\section{Korespondensi:}

\author{
Ahmad Zaki Yamani \\ Program Studi Teknik Industri, Institut Teknologi Telkom Purwokerto \\ Jl. D.I. Panjaitan No.128, Purwokerto Selatan, Banyumas, Indonesia
}




\section{PENDAHULUAN}

Pada era industri 4.0, para pelaku UMKM masih banyak menghadapi banyak permasalahan. Pelaku UMKM ini masih mengharapkan produk lokal sebagai salah satu sumber penghasilan mereka (Endaryono \& Djuhartono, 2018). Era globalisasi menuntut peningkatan inovasi produk dan jasa, pengembangan skill dari sumber daya manusia, pengembangan teknologi dan perluasan area pemasaran (Gunartin, 2017). UMKM menjadi wadah yang baik bagi penciptaan lapangan pekerjaan yang produktif. UMKM merupakan usaha yang bersifat padat karya, tidak membutuhkan persyaratan tertentu seperti tingkat pendidikan, keahlian (keterampilan) pekerja, dan penggunaan modal usaha relatif sedikit serta teknologi yang digunakan cenderung sederhana (Ananda \& Susilowati, 2017).

Pemerintah mendorong berdirinya UMKM agar masyarakat mampu memenuhi kebutuhan ekonominya dan berdaya saing. Usaha produktif yang hampir sebagian besar masih dilakukan menggunakan cara yang sangat sederhana seringkali menyebabkan omzet penjualan UMKM tersebut kurang maksimal (Sulistyandari, Widiastuti, Indriati, \& Nawarini, 2018). Usaha untuk memenuhi kebutuhan ekonomi adalah dengan disediakan koperasi, koperasi merupakan salah satu alternatif untuk memberdayakan ekonomi masyarakat (Alyas \& Rakib, 2017). Beberapa faktor yang dianggap menjadi penyebab meningkat jumlah pelaku UMKM antara lain (Junaidi, 2017): (1) Produk UMKM merupakan barang konsumsi dengan tingkat proses kimiawi yang sangat rendah; (2) UMKM tidak mudah terpengaruh krisis ekonomi; (3) Sebagian besar UMKM mengandalkan modal kepercayaan masyarakat sehingga pada saat krisis ekonomi, mereka terhindar dari beban bunga tinggi ; (4) Hampir tidak ada hambatan untuk keluar masuk dalam industri yang digeluti oleh UMKM; (5)
Banyaknya tenaga pengangguran akibat terbatasnya lapangan pekerjaan.

Berdirinya UMKM di kalangan masyarakat masih menimbulkan berbagai permasalahan. Permasalahan-permasalahan tersebut antara lain minimnya modal dan pengetahuan tentang karakteristik pasar. Minimnya modal dapat diantisipasi dengan adanya kredit lunak tanpa agunan yang disediakan pemerintah. Sedangkan pada permasalahan promosi, pelaku UMKM masih mengalami kendala dalam penggunaan teknologi informasi dikarenakan minimnya pengetahuan.

Pada penelitian yang dilakukan oleh Amin dan Dwi dengan judul Pengembangan Usaha Mikro Kecil dan Menengah (UMKM) Berbasis Industri Kreatif di kota Malang, menghasilkan data perkembangan UMKM di kota Malang berbasis industri kreatif dengan melihat kekuatan, kelemahan, ancaman dan peluang di sektor kuliner, kerajinan, fashion, musik, dan permainan interaktif, serta untuk menentukan strategi dan strategi utama untuk pengembangan UMKM berbasis industri kreatif di sektor kuliner, kerjinan, fashion, musik, dan permainan interaktif di Kota Malang. Kota Malang sudah memiliki banyak potensi di 15 sektor industri kreatif, dari semua sektor tersebut tiap sektor memiliki kekuatan, kelemahan, peluang dan ancaman yang berbeda. Selain itu, banyak permasalahan di tiap sektor seperti permasalahan Sumber Daya Manusia (SDM) seperti pada sektor kuliner, kerajinan, fashion, dan permainan interaktif (Ananda \& Susilowati, 2017).

Penelitian selanjutnya dilakukan oleh Dedi, Rahmi dan Shandy bahwa pelaku UMKM harus memahami digital marketing dengan media sosial dan hal yang perlu dilakukan (Es, Rahmi, \& Aditya, 2017), diantaranya adalah: (1) Membuat akun media sosial untuk usaha yang terpisah dari akun pribadi; (2) Membuat nama akun yang sederhana, mudah diingat, menjelaskan 
tentang usahanya, dan memiliki nama yang sama dengan platform media sosial lain yang digunakan; (3) Post secara berkala dan rutin, disesuaikan dengan "golden moment"; (4) Usahakan setiap post selalu berkaitan dengan usaha; (5) Buatlah tanda pagar (hashtag) unik yang mencirikan usaha kita dan gunakan itu di setiap post; (6) Jawab segala pertanyaan yang ditanyakan oleh follower untuk menandakan bahwa akun aktif.

Penelitian lainnya tentang ekonomi berbasi digital untuk pelaku UMKM dilakukan oleh Kristina Sedyastuti, penelitian tersebut menyatakan bahwa strategi untuk mengantisipasi mekanisme pasar yang makin terbuka dan kompetitif khususnya di kawasan Asean adalah penguasaan pasar, yang merupakan prasyarat untuk meningkatkan daya saing UMKM. Agar dapat menguasai pasar, maka UMKM perlu mendapatkan informasi dengan mudah dan cepat, baik informasi mengenai pasar produksi maupun pasar faktor produksi untuk memperluas jaringan pemasaran produk yang dihasilkan oleh UMKM. Aplikasi teknologi informasi pada usaha mikro, kecil dan menengah akan mempermudah UMKM dalam memperluas pasar baik di dalam negeri maupun pasar luar negeri dengan efisien. Pembentukan Pusat Pengembangan UMKM berbasis IT dianggap mampu mendorong pertumbuhan dan perkembangan usaha mikro, kecil, dan menengah di era teknologi informasi saat ini (Sedyastuti, 2018).

Salah satu kawasan yang mendukung penerapan teknologi informasi adalah kecamatan Paguyangan, Bumiayu. Daerah ini merupakan daerah wisata waduk penjalin yang memiliki potensi besar untuk dikembangkan. Oleh karena itu, penggunaan teknologi informasi sebagai sebuah wadah dalam promosi perlu ditekankan terutama bagi pelaku UMKM sebagai salah satu bagian penting dari perkembangan desa dan wisata. Analisis dapat berupa uraian seluruh persoalan yang dihadapi masyarakat mitra dari aspek sosial, budaya, religi, kesehatan, mutu layanan atau kehidupan bermasyarakat. Dapat juga berupa potensi dan peluang usaha masyarakat mitra dari aspek sumber daya, produksi dan manajemen usaha. Dengan mengacu pada analisis situasi, penentuan permasalahan yang utama/prioritas untuk masyarakat mitra yang bersifat spesifik, konkret, dan benar-benar dihadapi masyarakat mitra.

\section{METODE PELAKSANAAN}

\subsection{Metode}

Metode pelaksanaan dari kegiatan pelatihan pendampingan dan penguatan ekonomi lokal berbasis digital ini dilakukan dengan metode diskusi dengan format Pelatihan mengenai indentifikasi masalah yang sedang dihadapi pelaku UMKM utamanya dalam mengakses pasar menggunakan media teknologi.

\subsection{Peserta Kegiatan}

Kegiatan pelatihan ini diikuti oleh 56 peserta yang terdiri atas perangkat desa, pelaku UMKM, serta kelompok sadar wisata desa Winduaji, Kabupaten Brebes. Pengabdian ini dilaksanakan pada tanggal 17 Oktober 2017.

\section{HASIL DAN PEMBAHASAN}

Berdasarkan hasil pengamatan selama pelaksanaan pelatihan internet marketing pada pelaku UMKM di Desa Winduaji diperoleh hasil sebagai berikut:

a) Peserta memahami arti dan penerapan dari scalling up skill dalam hal akses teknologi informasi untuk keberlanjutan sebuah usaha

b) Penggunaan media sosial sebagai media promosi menjadikan peserta lebih terbuka dengan teknologi. Kelompok sadar wisata penjalin juga siap memfasilitasi peserta untuk mendapatkan layanan promosi di media sosial seperti facebook, instagram, youtube, twitter dan lain sebagainya.

Secara keseluruhan pelaksanaan kegiatan ini berjalan secara lancar. Hal ini dikarenakan komunikasi yang baik antara pemerintah desa, kelompok sadar wisata (pokdarwis) waduk penjalin dan pelaku UMKM. Materi yang diberikan tentang Pemanfaatan digital untuk penguatan ekonomi lokal pada pelaku UMKM di Desa Winduaji, Kabupaten Brebes, Jawa 
Vol. 18, No.1, Agustus 2019, pp. 24-28

Tengah. Media sosial sangat diperlukan dalam peningakatan marketing produk UMKM. Pengenalan dan strategi dalam marketing media sosial merupakan kunci awal bagaimana suatu desa/produk/adat dan lainnya dapat dengan cepat, efeektif dan efisien. Proses pemberian materi ditunjukkan pada gambar 1 .

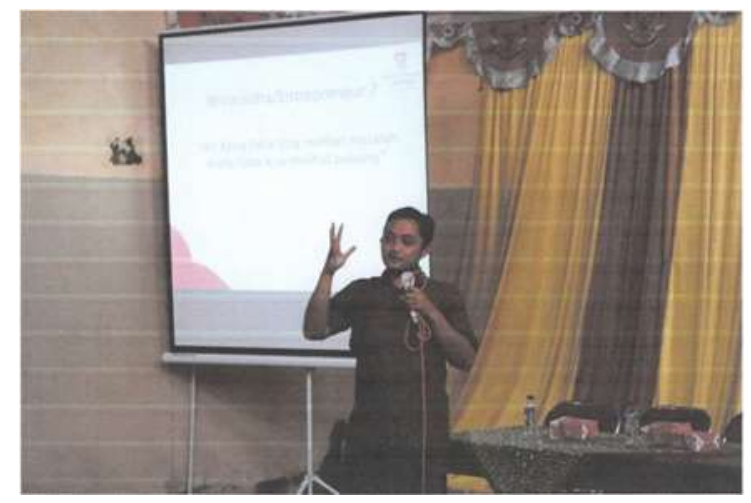

Gambar 1. Proses Pemberian Materi

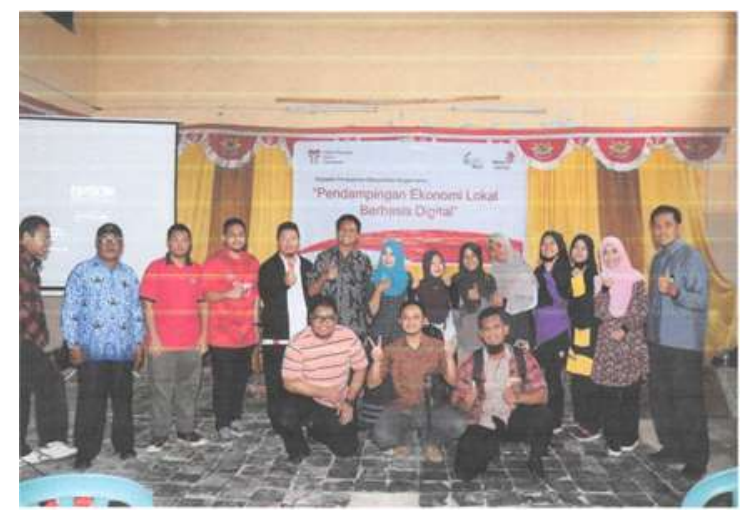

Gambar 2. Proses Foto Bersama

Faktor pendorong peserta menjadi antusias dikarenakan kebutuhan peserta akan ilmu tentang promosi lewat media sosial dan media digital yang lain. Selain itu adanya kemauan peserta untuk mengembangkan bisnisnya dari offline menuju online, menjadikanya sebagai motivasi dalam membantu perekenomian keluarga. Tindak lanjut kegiatan pelatihan ini adalah adanya harapan pemerintah desa, kelompok sadar wisata dan institusi pendidikan melakukan follow up kegiatan. Follow up kegiatan dapat dilakukan dengan pendampingan intensif pelaku UMKM serta mempromosikan produk mereka melalui media digital pemerintah desa atau kelompok sadar wisata waduk penjalin.

\section{KESIMPULAN}

Hasil kegiatan narasumber atau pengabdian kepada masyarakat menunjukkan bahwa peserta pelatihan dapat melakukan promosi dengan menggunakan media sosial untuk memasarkan produk UMKM melalui tanya jawab dan ceramah sehingga peserta dapat mengenal dan memahami materi pelatihan. Pelaku UMKM diharapkan dapat menerapkan materi tentang marketing digital untuk produk UMKM, desa wisata agar lebih dikenal dengan efektif dan efisien.

\section{UCAPAN TERIMA KASIH}

Ucapan terimakasih patut kami sampaikan kepada Lembaga Peneliitian dan Pengabdian Masyarakat (LPPM) IT Telkom Purwokerto yang sudah memberikan dukungan serta fasilitasi selama kegiatan, sementara itu kami juga mengucapkan terimakasih kepada Pemerintah Desa Winduaji atas undangan serta kepercayaanya untuk sinergi dengan IT Telkom kaitanya dengan kerjasama serta keberlanjutan desa binaan kampus sebagai upaya brigding technology for humanity.

\section{DAFTAR PUSTAKA}

Alyas, \& Rakib, M. (2017). Strategi Pengembangan Usaha Mikro, Kecil Dan Menengah Dalam Penguatan Ekonomi Kerakyatan (Studi Kasus pada Usaha Roti Maros di Kabupaten Maros). Sosiohumaniora, 19(2), 114-120.

Ananda, A. D., \& Susilowati, D. (2017). Pengembangan usaha mikro kecil dan menengah (umkm) berbasis industri kreatif di kota malang. Jurnal Ilmu Ekonomi, 10(10), 120-142.

Endaryono, B. T., \& Djuhartono, T. (2018). Membangun Jaringan Pasar Untuk Mengembangkan Usaha Produk Lokal Dalam Menumbuh Kembangkan Usaha Berbasis Sumber Daya Lokal Melalui Usaha Mikro Dan Keuangan Mikro. Sosio E-Kons, 10(3), 228-233.

Es, D. P., Rahmi, \& Aditya, S. (2017). Pemanfaatan Digital MARKETING Bagi Usaha Mikro, Kecil, Dan Menengah (Umkm) Di Kelurahan Malaka Sari, Duren Sawit. Jurnal Pemberdayaan Masyarakat Madani (JPMM), 1(1), 1-17. Gunartin. (2017). Penguatan Umkm Sebagai Pilar Membangun Ekonomi Bangsa. 
Madani : Indonesian Journal Of Civil Society

Vol. 18, No.1, Agustus 2019, pp. 24-28

Eduka Jurnal Pendidikan, Hukum Dan Bisnis, 1(V), 59-74.

Junaidi. (2017). Pelatihan Manajemen Keuangan sebagai Upaya Peningkatan Daya Saing UMKM dalam Menghadapi MEA di Kecamatan Tomoni Kabupaten Luwu Timur. Resona Jurnal Ilmiah Pengabdian Masyarakat, 1(1), 46-51.

Sedyastuti, K. (2018). Analisis Pemberdayaan

UMKM dan Peningkatan Daya Saing
Dalam Kancah Pasar Global. INOBIS: Jurnal Inovasi Bisnis Dan Manajemen Indonesia, 2(1), 117-127.

Sulistyandari, Widiastuti, E., Indriati, S., \& Nawarini, A. T. (2018). Pendampingan Usaha Pada Kerajinan Logam "Mandiri Etsa" Desa Pasir Wetan, Karanglewas, Banyumas. Jurnal Adimas, 02(1), 37-41. 